\title{
PENERAPAN TEKNOLOGI INFORMASI DALAM PENGEMBANGAN PARIWISATA BERBASIS SMART VILLAGE DESA AIKDEWA
}

\author{
Siti Puspita Hida Sakti MZ'), Marzuki²), Asslia Johar Latipah ${ }^{3)}$ \\ ${ }^{1,2)}$ Program Studi Sistem Informasi, STMIK Syaikh Zainuddin NW Anjani \\ ${ }^{3}$ Program Studi Teknik Informatika, Universitas Muhammadiyah Kalimantan Timur

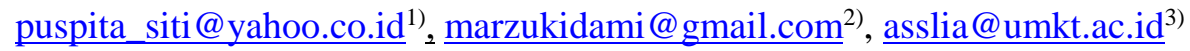

\begin{abstract}
ABSTRAK
Perkembangan teknologi informasi tidak bisa lagi dipisahkan dengan kehidupan sehari-hari, Konsep smart berbasis teknologi informasi terus dikembangkan dan diaplikasikan melalui smart city hingga area yang lebih kecil yaitu smart village. Dibangunnya infrastruktur dan jaringan internet, mendukung konsep smart village dalam memberdayakan masyarakat salah satunya dibidang pariwisata.

Meningkatkan pendapatan desa dibidang pariwisata dilakukan dalam bentuk pengembangan kemampuan, keterampilan, kemandirian, pemberdayaan, dan produktivitas masyarakat di bidang pariwisata berbasis teknologi informasi. Masyarakat diharapkan mampu menemukan potensi desa yang pengembangannya didukung dengan penerapan teknologi informasi guna peningkatan taraf hidup dan kualitas hidup masyarakat desa Aikdewa.

Smart village memberikan dukungan guna meningkatkan kepedulian dan empati terhadap permasalahan ekonomi, sosial dan budaya untuk diangkat menjadi aset ekonomis sehingga dapat meningkatkan pendapatan masyarakat guna mencapai hidup yang lebih sejahtera.

Smart village juga dapat menumbuhkan dan meningkatkan kemitraan untuk memiliki berbagai keterampilan (administrasi, pendidikan, dan teknologi informasi) sehingga dapat terwujud kerjasama yang baik dalam mengembangkan, memberdayakan, dan meningkatkan kemandirian usaha pariwisata sebagai salah satu pilar ekonomi keluarga.
\end{abstract}

Kata kunci: smart village, smart city, teknologi informasi, pariwisata, kearifan lokal

\begin{abstract}
The development of information technology can no longer be solved by everyday life. Smart concepts based on information technology continue to be developed and applied through smart cities to smaller areas of smart villages. Development of infrastructure and internet networks supporting the concept of smart villages in empowering the community one of which is in the field of tourism.

The increase in village income is carried out in the form of capacity development, skills, independence, empowerment, and community development in the field of information technology. The community is expected to discover the potential of villages supported by the application of information technology to improve the standard of living and quality of life of the Aikdewa village community.

Smart villages provide support in order to raise awareness and interest in the economic, social and cultural aspects to be raised as economic assets that can increase people's income in order to obtain a more prosperous life.

Smart villages can also foster and enhance partnerships to acquire various skills (administration, education, and information technology) so as to develop good collaboration in developing, empowering, and increasing the independence of tourism businesses as one of the pillars of the family economy.
\end{abstract}

Keyword: smart village, smart city, information technology, tourism, local wisdom

\section{Pendahuluan}

$\mathrm{P}$ erkembangan teknologi informasi semakin memudahkan pekerjaan manusia. Penggunaan teknologi informasi di berbagai bidang dan elemen masyarakat dibutuhkan demi efisiensi dan efektifitas pekerjaan manusia. Teknologi informasi didefinisikan sebagai perangkat keras dan infrastruktur jaringan yang dibutuhkan dalam penerapan sebuah sistem berbasis smart city. Penerapan teknologi informasi berbasis smart city memiliki area yang dapat diperkecil menjadi smart regency dan smart village. Smart city adalah manajemen pengelolaan aset perkotaan secara cerdas yaitu baik dan bijaksana. 
Penerapan smart village memerlukan penggunaan teknologi informasi secara inovatif mengembangkan potensi desa untuk meningkatkan kualitas hidup, efisiensi dan daya saing dalam aspek ekonomi, sosial dan lingkungan [4]. Penelitian mengenai smart city khususnya smart village masih perlu dikembangkan karena teknologi informasi berkembang begitu cepat dan penerapan smart village memerlukan dukungan dan komitmen seluruh elemen masyarakat desa untuk berbagi ide dan pikiran guna peningkatan kehidupan desa namun tetap tidak meninggalkan budaya luhur dan nilai kearifan lokal. Potensi desa perlu diperhatikan dalam penerapan smart village seperti pada Desa Aikdewa yang memiliki beberapa potensi dibidang pariwisata, letak geografis yang tidak jauh dari pusat kabupaten dan infrastruktur jaringan internet yang sangat mendukung .

Pariwisata merupakan salah satu sektor penting dalam perkembangan sebuah wilayah. Pariwisata telah menjadi aktifitas ekonomi penting bagi beberapa negara berkembang dalam usaha mengurangi kemiskinan dan meningkatkan kesejateraan masyarakat [8].

Beberapa tahun belakangan ini, tingkat kedatangan wisatawan baik dalam negeri maupun luar negeri mengalami kenaikan yang cukup signifikan. Tingginya penggunaan sosial media dan keinginan melakukan travelling membuat banyak kemunculan lokasi wisata baru yang cepat terkenal. Bahkan untuk menarik pengunjung, di berbagai lokasi wisata di bangun spot-spot photo yang unik dan menarik sehingga menjadi viral di media sosial. Lokasi wisata lama pasti memiliki berbagai infrastruktur yang mendukung sehingga wisatawan merasa nyaman dan kemudahan dalam mencari arah menuju lokasi wisata. Lokasi wisata tersebut akan sangat ramai dan akan sulit menemukan spot yang kosong untuk berphoto.

Namun berbeda dengan lokasi wisata yang baru dibuka atau yang kurang dikenal. Wisata ini dapat berupa lokasi yang awalnya hanya diketahui oleh penduduk lokal dan akses lokasi yang sulit serta informasi yang kurang. Selain itu sebuah lokasi wisata bisa saja wisata yang tidak terlalu cantik namun untuk menarik pengunjung, mereka membuat spot-spot photo yang unik dan instagramable dengan sedikit editan photo sehingga lokasi wisata baru tersebut menjadi semakin terkenal.

Seiring terkenalnya Lombok sebagai daerah wisata, maka beberapa daerah mulai menjadikan pariwisata sebagai Pendapatan Asli Daerah (PAD) yang besar selain sumber daya alam lainnya. Kecamatan Pringgasela sebagai salah satu daerah yang memiliki banyak lokasi wisata dan baru-baru ini telah dibuka jalur pendakian melalui desa Timbanuh kecamatan
Pringgasela. Desa lain seperti Aikdewa juga memiliki lokasi wisata yang awalnya hanya dikenal oleh penduduk lokal, namun tingginya minat anak muda untuk mengeksplor daerahnya sehingga lokasi-lokasi yang awalnya sebagai tempat pemandian warga lokal di sepanjang sungai menjadi terkenal karena mulai dikunjungi oleh orang luar desa dan akses jalan yang lebih mudah sehingga diperlukan sebuah informasi sebagai petunjuk. Misalnya papan penunjuk jalan dan informasi lokasi wisata dalam bentuk pamflet dan pengunjung juga akan merasakan kearifan lokal dengan keramahan yang ditemui disepanjang jalan di desa Aikdewa.

Tingginya tingkat kunjungan wisatawan tentunya membantu peningkatan masyarakat lokal secara ekonomi melalui pariwisata ini namun banyak sisi negatifnya seperti dapat merusak moral dan pikiran kaum muda serta kurangnya penghormatan akan penduduk lokal. Oleh karena itu, perlunya awiq-awiq atau aturan desa untuk menjaga tingkah laku dan didukung peraturan pemerintah Kecamatan dan keatasnya demi kebaikan baik penduduk lokal maupun wisatawan. Kondisi ini juga dapat didukung oleh kearifan lokal masyarakat Aikdewa yang mengandung nilai-nilai pelestarian kawasan wisata. Masyarakat Aikdewa yang didukung oleh Pemerintah Desa Aikdewa memiliki kedekatan emosional dan pemikiran terhadap sumber daya alamnya, yang kemudian melahirkan sikap dan perilaku nyata dengan mempertimbangkan kapasitas pariwisata. Masyarakat Aikdewa sebagian besar juga memiliki ketergantungan hidup mereka kepada sumber daya alam di daratan. Namun demikian, mereka tergolong masyarakat yang tidak gagap teknologi informasi dan kedekatan secara sosial masih tinggi. Dapat dilihat dari gotong royong yang sangat melekat dan sikat hormat kaum muda terhadap tokoh masyarakat, serta memiliki pengetahuan dan keterampilan untuk mengelola sumber dayanya.

Terlebih desa Aikdewa memiliki jumlah mata air yang banyak karena berada dekat dengan lereng gunung Rinjani. Pasokan air masyarakat Aikdewa berasal dari mata air-mata air yang dialirkan ke hampir seluruh rumah. Bila pasokan air ini terganggu, ada penduduk yang mandi di sungai yang memiliki mata air atau mencuci dan lain sebagainya. Kawasan mata air bagi masyarakat Aikdewa tidak hanya memiliki sumber daya alam yang dapat dimanfaatkan untuk kepentingan ekonomi, tetapi budaya dan tradisi yang harus dijaga untuk kepentingan hidup masyaraka t dan dipercaya bagi kehidupan leluhur.

Masyarakat Aikdewa memiliki kearifan lokal berupa sejumlah tradisi, anjuran atau pantangan yang masih berlaku secara turun temurun yang dipraktek- 
kan, dipelihara dan ditaati oleh masyarakat Aikdewa. Dikaji secara ilmiah tradisi ini mengandung nilai-nilai lokal bagi pelestarian kawasan hutan dan lingkungan wisata. Nilai-nilai lokal ini perlu dijaga dan diperkuat agar tidak tergilas oleh kemajuan dan tantangan hidup masyarakat.

Pemerintah Desa Aikdewa sangat dibantu dengan adanya kelompok pemuda yang sangat antusias dalam memajukan desa, ditunjukkan dengan banyaknya ide-ide baik dalam bentuk memperkenalkan tradisi dan budaya adat serta kegiatan yang selalu mengikutsertakan semua elemen masyarkat dan dilaksanakan di beberapa tempat sambil memperkenalkan daerah wisata dan produk khas Aikdewa. Usaha pemerintah desa dan seluruh lapisan masyarakat telah memberi dampak positif bagi terpeliharanya ekosistem dan ka- wasan wisata sehingga saat ini wilayah desa Aikdewa menjadi salah satu desa yang memiliki banyak tempat wisata di Kecamatan Pringgasela, Selain itu masyarakat dapat memperoleh tambahan pendapatan dari jasa pariwisata ini.

Penerapan smart village akan menjadikan Desa Aikdewa sebagai kawasan melek teknologi informasi melalui pengembangan pariwisata dengan mengoptimalkan sumber daya alam dan sumber daya manusia dengan mengumpulkan dan menyebarkan informasi-informasi terbaru tentang lokasi-lokasi wisata terutama lokasi wisata baru yang didasarkan pada nilai-nilai kearifan lokal.

\section{METODE PENELITIAN}

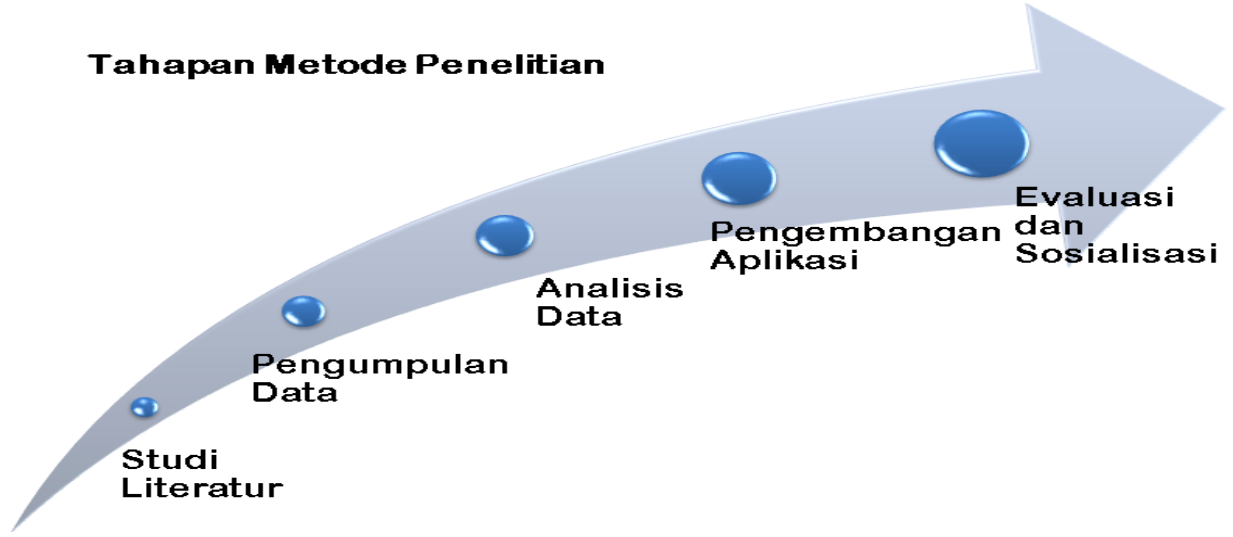

Gambar 1. Metode Penelitian

Berdasarkan metode penelitian yang digambarkan pada Gambar 1 dapat diketahui bahwa terdapat empat tahapan, yaitu:

\section{A. Studi Literatur}

Literatur dibutuhkan untuk mendukung perancangan mulai dari penemuan konsep, proses desain hingga implementasi dan evaluasi. Literatur yang digunakan berasal dari survey, jurnal dan dokumen yang berkaitan dengan smart city, smart village, dan sistem informasi pariwisata meliputi RPJMN 2015-2019 yaitu roadmap smart city di Indonesia, lokasi wisata, potensi sekitar lokasi wisata, foto dan deskripsi lokasi wisata. Literatur berisi landasan teori dan solusi masalah yang bersumber pada referensi topik atau masalah terkait penelitian

\section{B. Pengumpulan Data}

Pada tahap ini dilakukan pengumpulan data terkait dengan permasalahan pada pelayanan masyarakat desa Aikdewa. Dalam pelaksanaannya proses pengumpulan data dilakukan dengan melakukan kunjungan ke kantor desa dan melakukan wawancara pada perangkat desa untuk mengetahui desain aplikasi yang diinginkan meliputi desain database dan interface serta melakukan survei kebutuhan aplikasi yang akan dibuat.

Tabel 1. Tabel Kebutuhan Data

\begin{tabular}{|c|l|}
\hline No & \multicolumn{1}{|c|}{ Komponen Data } \\
\hline 1 & Nama objek wisata \\
\hline 2 & Lokasi objek wisata \\
\hline 3 & Kategori objek wisata \\
\hline 4 & Deskripsi lokasi wisata \\
\hline 5 & Fasilitas yang tersedia \\
\hline 6 & Spot-spot photo di lokasi wisata \\
\hline 7 & Potensi sekitar lokasi wisata \\
\hline 8 & Lampiran: foto, dokumen, link \\
\hline 9 & Rute dan akses lokasi wisata \\
\hline 10 & Produk wisata \\
\hline 11 & Wisata atraksi budaya \\
\hline
\end{tabular}




\begin{tabular}{|l|l|}
\hline 12 & Jenis stakeholder \\
\hline 13 & Keterampilan masyarakat \\
\hline 14 & Informasi tambahan: pengalaman pengunjung \\
\hline
\end{tabular}

Tabel 2. Stakeholder Smart Village

\begin{tabular}{|c|l|}
\hline No & \multicolumn{1}{|c|}{ Stakeholder } \\
\hline 1 & Para pemangku kebijakan, Kepala Desa \\
\hline 2 & Dinas Pariwisata \\
\hline 3 & Kelompok Masyarakat \\
\hline 4 & Kelompok Pemuda/Karang Taruna \\
\hline 5 & Para Pemilik/Pengelola Lokasi Wisata \\
\hline
\end{tabular}

Tabel 3. Indikator Penerapan Konsep Smart Village

\begin{tabular}{|c|l|}
\hline No & \multicolumn{1}{|c|}{ Indikator } \\
\hline 1 & Menerapkan penggunaan teknologi informasi \\
\hline 2 & Mengembangkan potensi desa \\
\hline 3 & Meningkatkan ekonomi \\
\hline 4 & Menciptakan kualitas hidup masyarakat \\
\hline
\end{tabular}

\section{Data Desa Aikdewa}

1. Keadaan Geografis Desa Aikdewa

Desa Aikdewa terletak di Kecamatan Pringgasela, dengan ketinggian 600 meter dari laut, desa ini berbatasan dengan beberapa desa lain yaitu:

a. Sebelah Utara dibatasi oleh Desa Pringgasela

b. Sebelah Selatan dibatasi oleh Desa Pringgasela Selatan

c. Sebelah Timur dibatasi oleh Desa Jurit

d. Sebelah Barat dibatasi oleh Desa Pringgasela

\section{Topografi Desa Aikdewa}

Secara umum tanah di Desa Aikdewa adalah tanah kering, Walaupun demikian terdapat sebagian lahan subur yang digunakan untuk menghasilkan produksi di bidang pertanian antara lain jagung, padi, tomat, kubis, mentimun, cabe, terong, dan kol. Selain itu, tanah yang kering digunakan oleh penduduk sekitar untuk perkebunan dengan menanam buah-buahan seperti jeruk, mangga, pepaya, nanas, dan pisang. Sisa lahan lainnya digunakan untuk peternakan sapi, ayam dan kambing.

\section{Demografi Desa Aikdewa}

Masyarakat Desa Aikdewa 99,9\% beragama Islam. Untuk pelaksanaan ibadah terdapat 21 Masjid dan 69 Mushalla yang tersebar diseluruh desa. Sedangkan jumlah penduduk lebih kurang 11,951.

\section{Potensi Desa Aikdewa}

a. Mata Pencaharian

\begin{tabular}{|l|l|}
\hline No & Jenis Mata Pencaharian \\
\hline 1 & Petani/ Buruh Tani \\
\hline 2 & Pedagang \\
\hline 3 & Pegawai Negeri \\
\hline 4 & Guru/ Karyawan Swasta \\
\hline 5 & Penjahit \\
\hline 6 & Sopir/Ojek \\
\hline 7 & Pengrajin \\
\hline 8 & Tukang Bangunan \\
\hline 9 & Tekong/PL \\
\hline 10 & TNI/Polri \\
\hline 11 & Peternak \\
\hline 12 & Pembantu Rumah Tangga (PRT) \\
\hline 13 & Perawat/Dokter \\
\hline
\end{tabular}

b. Hasil-Hasil Produksi Masyarakat Desa Aikdewa

1) Tanaman Pangan

Dalam hal ini tanaman padi dan jagung merupakan hasil utama pertanian di desa Aikdewa. Selain itu, ada juga petani yang menanam kol, ubi dan kacang-kacangan.

\section{2) Peternakan}

Penduduk di beberapa dusun di Desa Aikdewa ada yang beternak ayam, bebek, dan sapi. Tetapi tidak ada yang memelihara dalam jumlah besar. Selain itu ada yang memelihara kerbau untuk membajak disawah.

\section{3) Perikanan}

Masyarakat Aikdewa banyak yang memiliki kolam ikan air tawar. Biasanya dipelihara sebagai hiasan dan dikonsumsi sendiri. Tetapi ada beberapa kolam ikan air tawar yang sengaja memelihara ikan untuk dijual. Banyaknya kolam di Aikdewa ini dipengaruhi oleh jumlah mata air dengan debit air yang besar.

\section{4) Perkebunan}

Perkebunan di Desa Aikdewa tidak luas hanya terletak disepanjang aliran sungai dengan pohon bambu dan kelapa yang mendominasi. Adanya pohon kelapa dan bambu membuat aliran air dari mata air tidak akan berhenti.

5) Kehutanan 
Hutan di Desa Aikdewa sangat sedikit walaupun dekat dengan kaki gunung Rinjani tetapi wilayah hutannya telah diubah menjadi lahan pertanian dan perumahan. Hutan yang masih tersisa umumnya terletak disepanjang sungai. Pepohonan mendapatkan air yang cukup sehingga dapat tumbuh subur.

\section{c. Hasil Kerajinan dan Industri Penduduk}

Hasil Kerajinan Penduduk sangatlah banyak dapat kita lihat dari keseharian penduduk yang beraktivitas sesuai dengan persepsi masing-masing. Ada yang membuat kerajinan tangan, makanan bahkan ada yang membuat obat-obat tradisional seperti jamu dan minyak untuk terapi pijat akupuntur. Masyarakat yang lainnya hidup juga sebagai buruh tani, buruh bangunan bahkan banyak yang menjadi TKI yang pergi ke Malaysia, Brunei Darussalam, Korea, Arab Saudi, dll.

\section{Sosial Budaya dan Pendidikan}

a) Adat Istiadat di Desa Aikdewa

Kombinasi antara adat dan agama masih sangat kental. Hal ini dapat dilihat dari masyarakat yang majemuk masing-masing sebagai ciri dari keragaman masyarakat Desa Aikdewa. Hal ini dapat dilihat dari upacara perkawinan, acara layatan, acara pesta dan didalam memperingari hari-hari raya besar Islam. Masyarakat begitu semangat dalam memenuhi kebutuhan hidupnya sehari-hari. Hal ini nampak jelas dari jam kerja masyarakat Desa Aikdewa sendiri.

b) Kesenian yang menjadi kesukaan dan perkembangan

Sejak dahulu Desa Aikdewa dikenal sebagi daerah seni karena menjamurnya banyak bentuk keseniann seperti grup band, rudat,dll Seiring dengan kemajuan zaman saat ini masyarakat Aikdewa juga mengimbangi dengan keterampilan-keterampilan dalam bidang seni antara lain terbentuknya grup band, grup qasidah dan bahkan yang pandai memetik gitar dan piano.

\section{c) Pendidikan / Sekolah di Desa Aikdewa}

Lembaga pendidikan di Desa Aikdewa bagaikan jamur dimusim hujan dapat dilihat dari berdirinya lembaga pendidikan baik yang bersifat formal dan non formal.

\section{Kebersihan Lingkungan dan Kesehatan}

a) Sumber air minum
Masyarakat Aikdewa memenuhi kebutuhan air minumnya langsung mengambil dari mata air Aikdewa menggunakan ember atau galon dan air tersebut langsung dapat diminum tanpa dimasak karena sangat higienis dan jernih.

b) MCK (mandi, cuci, kakus)

Sebagian besar penduduk sudah sadar akan pentingnya jambanisme. Tetapi di lingkunganlingkungan tertentu seperti di sekitar sungai masyarakat membuang kotoran di sungai atau tempat-tempat lain.

\section{Keadaan Rumah Penduduk}

Sekitar $85 \%$ rumah penduduk sudah permanen dan sisanya masih menggunakan rumbia sebagai atap rumah dan berdinding bedek. Masyarakat desa Aikdewa kebanyakan tidak memiliki halamn rumah dan rumah-rumahnya berdempet-dempetan sehingga masalah dalam rumah bisa menyebar karena mudahnya didengar oleh tetangga.

Masyarakat membangun rumahnya dipinggir jalan raya tetapi karena perluasan wilayah pemukiman dan semakin tingginya harga tanah dipinggir jalan, banyak masyarakat Aikdewa membangun rumah di daerah pedalaman atau di tengah sawah. Walaupun di tengah sawah sudah ada jalan yang dapat dilalui bahkan dengan mobil walaupun masih berupa jalan tanah.

\section{Keluarga Berencana (KB)}

Kesadaran masyarakat akan pentingnya KB sudah patut dapat acungin jempol. Setiap anggota keluarga sudah sadar akan pentingnya pengaturan kehamilan.

\section{Administrasi Desa, Kelembagaan dan Struktur Or-} ganisasi Desa Aikdewa

Roda Pemerintahan Desa Aikdewa berjalan dengan lancar walaupun Desa Aikdewa masih seumur jagung tepatnya tanggal 30 September 2010 menjadi Desa definitif namun dalam hal administrasi dan pembangunan tetap berjalan tidak ketinggalan.

\section{Analisis Data}

Pada tahap ini dilakukan analisis untuk mengetahui permasalahan, kebutuhan, kekurangan dan kelebihan, batasan masalah dan solusi dari permasalahan. Tahap ini terkait dengan proses pelayanan masyarakat sudah cukup baik namun masih ada poten- 
si pelayanan yang belum optimal. Dukungan infrastrutur dan fasilitas perangkat komputer yang terhubung dengan internet serta masyarakat desa yang sudah melek teknologi sehingga dapat mendukung penerapan smart vilalge khsuusnya bidang pariwisata.

\section{Pengembangan Aplikasi}

Proses ini menghasilkah alternatif solusi berupa rancangan desain sistem berkonsep smart village. Pata tahap ini juga dilakukan uji rancangan sebelum sistem berbasis smart village diimplementasi. Dari hasil analisis diperlukan adanya pengembangan aplikasi yang dapat membuat proses pelayanan dan penyebaran informasi menjadi lebih optimal. Sebagai bagian dari pengembangan dan pembangunan smart village diperlukan stakeholder yang memahami dan mendukung proses ini.

\section{E. Evaluasi}

Pada tahap ini, proses evaluasi dilakukan dengan melakukan uji coba aplikasi secara blackbox untuk mengetahui fungsionalitas aplikasi secara umum. Dari hasil uji coba tersebut kemudian akan dilakukan perbaikan jika masih ada yang perlu diperbaiki jika tidak maka akan dilakukan proses evaluasi lanjutan yaitu uji coba integrasi dengan aplikasi yang sudah ada di desa Aikdewa dan publikasi server database secara online untuk pelaksanaan sinkronisasi data.

Selain tahapan-tahapan diatas, ada tahapan lain yaitu proses sosialisasi dalam penerapan aplikasi pada perangkat desa dan perwakilan masyarakat. Proses sosialisasi merupakan lanjutan dari evaluasi yang dapat menentukan tingkat keberhasilan penerapan dan pemanfaatan penggunaan aplikasi berbasis smart village.

\section{HASIL DAN PEMBAHASAN}

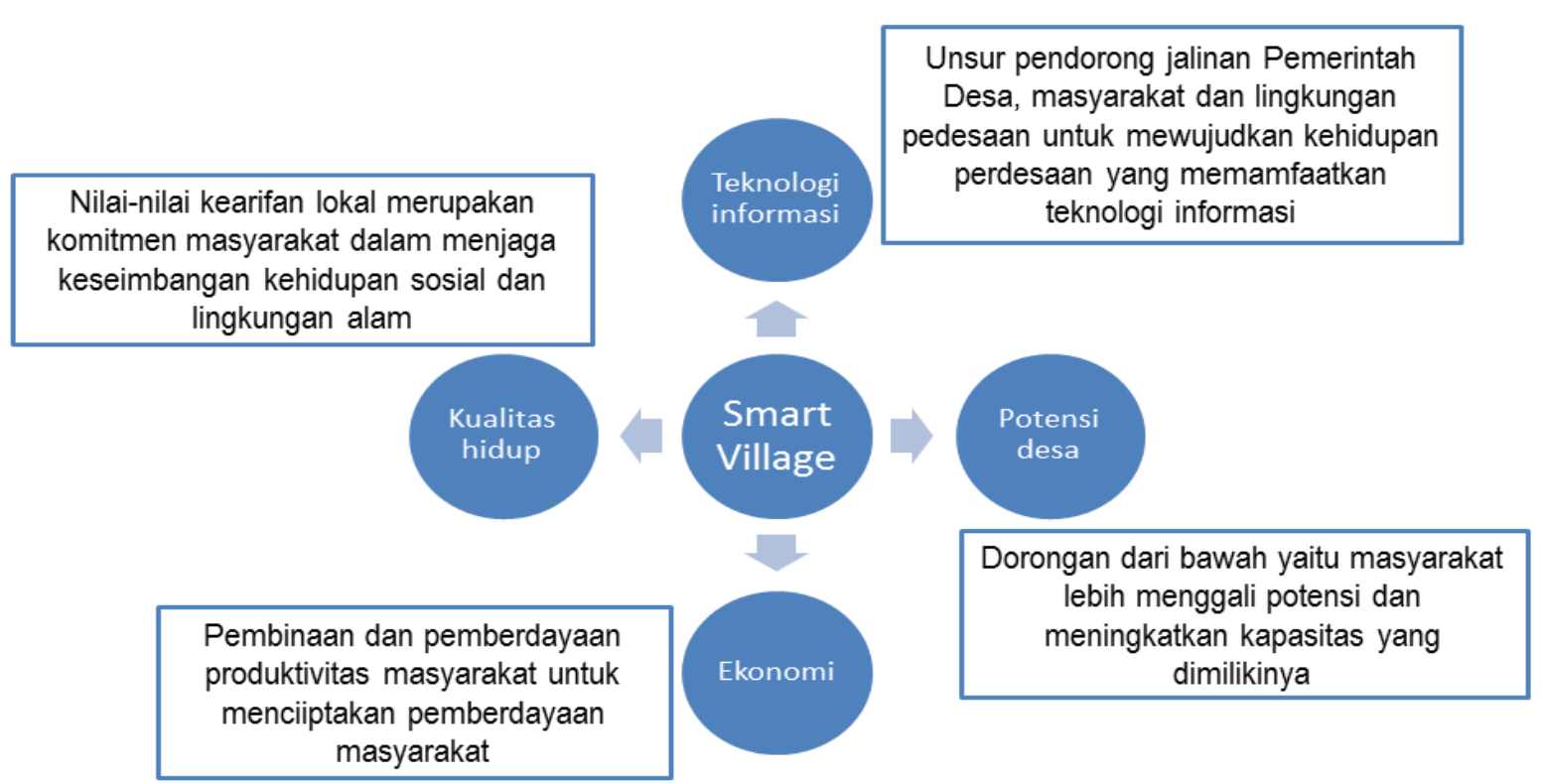

Gambar 2. Model Alternatif Penerapan Indikator Konsep Smart Village [Siti Puspita HSM, 2020]

\section{Usulan Uraian Indikator Perencanaan Smart Vil- lage Desa Aikdewa}

a) Melakukan survey lokasi penelitian, mengidentifikasi nilai-nilai kearifan lokal dan kebutuhan keterampilan yang dapat dipraktikkan pada pengembangan, pengelolaan dan pelestarian kawasan wisata

b) Menghimpun dan memetakan potensi dan tantangan sumber daya di wilayah desa Aikdewa

c) Sosialisasi konsep smart village yang diterapkan dalam ekosistem kawasan wisata pedesaan, sumber daya dan mengaitkan konsep teknologi informasi dalam pengumpulan dan penyebaran informasi tentang lokasi dan akses wisata khususnya wisata baru desa Aikdewa yang didukung dengan perbaikan infrastruktur dan penciptaan ide-ide menarik yang sesuai dengan aturan adat istiadat dan aturan Pemerintah Desa

d) Memberikan materi secara teori dan praktek dalam pengolahan sumber daya alam khususnya di bidang pariwisata guna pemberdayaan ekonomi masyarakat desa Aikdewa dengan memaksimalkan pendapatan desa Aikdewa melalui retribusi lokasi wisata baru yang memiliki spot-spot photo menari dan pasar mingguan di salah satu lokasi wisata secara bergantian

e) Diversifikasi produk sumber daya alam seperti 
- Pengembangan produksi makanan khas ataupun produk barang yang khas dengan sistem penjualan yang mendukung pengembangan smart village

- Pengembangan dan penataan lokasi wisata baru untuk menunjang kawasan pariwisata dengan mengumpulkan informasi dari masyarakat lokal tentang lokasi wisata baru, memperbaharui (update) informasi lokasi wisata baru dan pelatihan penggunaan website terkait informasi tentang wisata baru desa Aikdewa karena bahkan masyarakat lokal pun tidak mengetahui lokasi wisata baru di daerahnya sendiri

- Pembuatan video dokumentasi desa Aikdewa yang menonjolkan potensi pariwisata dan kebudayaaan desa Aikdewa.

- Peningkatan mutu sumber daya manusia melalui pendidikan

f. Pelestarian nilai sosial budaya lokal seperti:

- Melaksanakan rangkaian acara adat pada salah satu lokasi wisata baru terkait yang informasinya disebarluaskan baik melalui website desa maupun media-media sosial untuk menarik minat pengunjung pariwisata dan melahirkan ide-ide kreatif kaum muda dalam mengenalkan dan melestarikan budaya

- Lomba Lintas Alam dengan menyusuri kawasan-kawasan wisata desa, mengenalkan rute dan akses kawasan masyarakat desa dan suasana pedesaan yang masih alami

- Pengamalan budi pekerti dan keagamaan pada kegiatan-kegiatan budaya dan pariwisata meskipun diterjang arus teknologi informasi yang kuat namun esensi dari smart village untuk mengenalkan potensi desa dapat dilakukan dari berbagai sisi dan cara. Kesemuanya ini sebagai bagian dari pembedayaan dan meningkatkan taraf hidup masyarakat.

g. Peningkatan mutu lingkungan seperti pelayanan kesehatan adalah salah satu bagian yang akan didukung guna pembangunan smart village khususnya smart living sehingga kehidupan didesa tidak mengurangi kesejahteraan masyarakat

\section{Analisis Implementasi Usulan Indikator Perencanaan Smart Village Desa Aikdewa}

1. Pendampingan pembelajaran konsep-konsep teknologi informasi yang relevan dengan nilainilai kearifan lokal masyarakat Aikdewa untuk mendukung pembangunan smart village dalam pengelolaan ekosistem yang menjaga keberadaan mata air sepanjang sungai, pelestarian sumber daya alam yang memberikan dampak positif pada perubahan perilaku masyarakat sekitar, pengenalan pariwisata lokal, penelusuran budaya, tradisi dan adat yang tidak mengurangi keramahan penduduk lokal terhadap wisatawan dan kedatangan wisatawan tidak membawa dampak buruk bagi budaya ketimuran kaum muda di desa Aikdewa. Kegiatan ini diikuti oleh Pemerintah Desa, tokoh masyarakat, unsur pemuda, Dinas Pariwisata dan pemilik kawasan wisata. Metode yang digunakan adalah diskusi dan pelatihan keterampilan menggunakan media audio-visual tentang ekosistem pariwisata pedesaan dan memperkenalkan kebudayaan yang ada. Praktek lapangan kegiatan ini dapat dilakukan sebagai implementasi konsepkonsep teknologi informasi pada pelayanan yang diberikan pemilik dan pengelola wisata kepada pengunjung kawasan wisata sesuai dukungan dan arahan Pemerintah Desa.

2. Penerapan teknologi informasi berkonsep smart village diimplementasikan pada kegiatan pemberdayaan masyarakat. Analisis dan perancangan sistem berbasis smart village memerlukan kepekaan masyarakat desa dalam melihat permasalahan dan potensi yang dimiliki oleh Desa Aikdewa khususnya bidang pariwisata. Perlunya pemberdayaan masyarakat sebagai tujuan transfer pengetahuan penggunaan teknologi informasi dan pengimplementasian pada lingkungan hidup yang lebih bersifat ilmiah. Dalam mendukung implementasi konsep smart village, masyarakat desa Aikdewa dapat membagikan pengalaman mereka dan tetap memelihara nilainilai kearifan lokal serta memanfaatkan sumber daya alam khususnya pengembangan pariwisata desa Aikdewa. Masyarakat desa akan terlatih dan kreatif dalam mengatasi masalah dengan pendekatan dan metode yang sesuai dengan kebutuhan masyarakat. Melalui kegiatan pengembangan pariwisata desa Aikdewa yang ditunjang dengan teknologi informasi, diperlukan pemahaman mengenai pelestarian nilai-nilai kearifan lokal serta pengelolaan lokasi wisata khususnya lokasi wisata baru bagi kesejahteraan masyarakat

3. Pelatihan keterampilan pada pengolahan sumber daya alam untuk menjadi produk yang 
bernilai ekonomis namun tetap mempertahankan pelestarian ekosistem dan nilai-nilai kearifan lokal. Pelatihan ini diberikan dalam rangka persiapan implementasi konsep smart village yang diikuti ibu-ibu rumah tangga dan para remaja sebagai bagian dari masyarakat desa, dengan pengajar berpengalaman yang memiliki keterampilan dalam mengolah hasil sumber daya alam menjadi produk makanan atau produk barang yang dapat dijual. Pelatihan ini didahului dengan pengenalan bahanbahan lokal dan teknologi pengolahan menjadi produk berupa teknik pengawetan dan pengemasan produk makanan yang higienis sehingga dapat dipasarkan baik pada kawasan wisata atau tempat-tempat lainnya.

4. Pendampingan keterampilan pengolahan limbah rumah tangga menjadi produk yang bernilai ekonomis. Kegiatan ini diikuti ibu-ibu rumah tangga dengan instruktur yang memiliki kepakaran dan proses pendampingan keterampilan mengolah limbah rumah tangga seperti plastik dan limbah organik lain menjadi produk souvenir. Metode yang digunakan adalah praktek keterampilan pembuatan dan pengolahan produk seperti teknik pembuatan dan pengemasan produk. Praktek keterampilan didahului dengan pengenalan bahan lokal, desain dan teknologi pembuatannya.

5. Mengembangkan ide-ide kreatif yang mengupayakan efisiensi biaya pengembangan pariwisata melalui pembuatan spot-spot photo yang menarik dan unik dengan memanfaatkan sumber daya alam sekitar lokasi wisata yang dilandasi oleh pemahaman teknologi informasi guna meningkatkan pendapatan masyarakat Aikdewa. Ide-ide ini dapat memunculkan lokasi wisata baru termasuk menjadi pusat kajian tentang kebudayaan daerah dan kajian nilai-nilai kearifan lokal bagi pengelolaan kawasan pariwisata

6. Penataan infrastruktur dan akses menuju lokasi wisata sebagai salah satu sarana percepatan pembangunan dan perekonomian daerah serta mengapresiasikan nilai-nilai kearifan lokal. Kegiatan ini merupakan koordinasi pemerintah desa dan seluruh elemen masyarakat desa. Penataan infrastruktur dan akses menuju lokasi wisata melibatkan pemilik lokasi wisata dan masyarakat di kawasan wisata yang terkait. Metode yang digunakan dengan metode partisipatif.
7. Penyusunan desain dan impelementasi website mengenai pariwisata serta sosialisasi website tersebut yang ditunjang dengan pelatihan tentang pengembangan dan pengelolaan pariwisata desa dan tata kelola kawasan wisata kepada masyarakat terkait. Penyusunan desain melibatkan pemerintah desa, pemilik kawasan wisata dan masyarakat terkait yaitu masyarakat yang berada di kawasan wisata dan kawasan akses menuju kawasan wisata. Pembuatan website informasi pariwisata desa Aikadewa akan dikelola perangkat desa dan pembuatan papan petunjuk arah serta pembuatan plang nama lokasi wisata di setiap akses jalan menuju lokasi wisata. Metode yang digunakan adalah diskusi dan presentasi.

8. Pembangunan pondok informasi dan penataan display informasi tentang lokasi wisata termasuk papan penunjuk arah, peta rute dan fasilitas yang ada di masing-masing lokasi wisata. Pekerjaan pembangunan pondok dilakukan secara bersama-sama oleh seluruh elemen masyarakat dipimpin pemerintah desa.

9. Sosialisasi pengembangan dan pengelolaan pariwisata sebagai sarana penelitian dan pengabdian menggunakan konsep teknologi informasi dan berbasis nilai-nilai kearifan lokal kepada pemerintah desa, perguruan tinggi dan pemangku kepentingan lain di desa. Kegiatan sosialisasi dilakukan dalam bentuk kunjungan langsung oleh kepala desa, Dinas pariwisata, LSM, dan pemerhati masalah pariwisata. Dalam kegiatan ini disiapkan brosur yang berisi infornasi tentang kawasan wisata di desa Aikdewa.

10. Meningkatkan kerjasama yang baik antara Pemerintah Desa dengan pemilik lokasi wisata. Bila lokasi wisata merupakan kawasan yang dimiliki oleh banyak orang, maka pengelolaannya harus berdasarkan musyawarah agar tidak timbul polemik dan sengketa antar warga. Masyarakat bertanggung jawab penuh akan keamanan kawasan wisata dan mampu membuka peluang kerja serta menaikkan pendapatan desa. Kegiatan pelatihan dapat digunakan sebagai sarana menyalurkan pendapat masing-masing pemilik kawasan wisata dan bertukar pendapat serta ide-ide yang akan semakin memperkenalkan lokasi wisata khususnya kawasan wisata baru. Di beberapa lokasi wisata diperlukan warungwarung kecil yang menjual produk khas daerah sebagai bagian dari ide untuk menarik 
wisatawan serta membantu dalam pengadaan bangunan toilet dan mushalla. Tentunya karena ini kerjasama pemerintah desa, masyarakat desa dan pemilik kawasan wisata, maka harus disesuaikan dengan kemampuan desa dan batas-batas yang mampu di biayai oleh desa.

11. Dukungan masyarakat ini diharapkan dapat mendorong mitra lainnya dalam membantu pengelolaan sumber daya pariwisata baru. Pemerintah desa diharapkan menetapkan peraturan desa sesuai dengan peraturan pemerintah diatasnya terkait pemanfaatan dan pelestarian sumber daya wisata daerah dan pelestarian nilai-nilai kearifan lokal.

\section{KESIMPULAN}

Desa Aikdewa yang berada di kawasan dekat dengan lereng gunung Rinjani memiliki banyak mata air dan sungai dengan aliran air yang besar. Hal ini membuat letak lokasi-lokasi wisata berada pada kawasan dekat dengan air. Selain itu, kehidupan masyarakat desa Aikdewa tidak jauh dengan air dan banyak kegiatan rumah tangga yang dilakukan dekat dengan mata air. Masyarakat Aikdewa jarang memiliki sumur sehingga air yang meraka gunakan adalah air yang disalurkan dari mata air-mata air yang berada dibagian hulu desa. Bila terjadi banjir atau pasokan air putus dan berkurang, maka akan sangat mempengaruhi kegiatan rumah tangga. Selain itu, masih banyak masyarakat desa yang mandi dan mencuci di sungai. Aliran air yang besar juga digunakan untuk perikanan dengan membuat kolam-kolam ikan yang ikannya di jual atau ikan sebagai konsumsi sendiri.

Agar kesediaan air tetap terjaga maka ekosistem kawasan hutan di hulu atau kawasan dekat mata air harus dijaga serta penggunaan air yang tepat. Selain itu, penggunaan air di kawasan wisata perlu diperhatikan agar tidak mengganggu jalannya pasokan air. Daerah sekitar desa Aikdewa adalah kawasankawasan wisata berbentuk wisata pedesaan dengan suhu yang tidak terlalu panas, memiliki aliran sungai dan mata air yang besar. Kondisi Desa Aikdewa tidak jauh berbeda dengan desa sekitarnya yang memiliki tempat-tempat wisata.

Untuk itu, perlu adanya pengembangan dan pengelolaan atas kawasan wisata khususnya wisata baru dan wisata lama yang belum dikenal masyarakat luas guna peningkatan jumlah kunjungan wisata. Selain itu, gempuran globalisasi yang terkadang tidak sesuai dengan nilai-nilai kearifan lokal walaupun ratarata masyarakat Aikdewa telah menggunakan teknologi-teknologi terbaru, bila tidak dibuat aturan atau dis- esuaikan dengan budaya dan adat istiadat maka sifat ketimuran yang turun temurun akan tergerus.

Oleh karena itu, penelitian ini merupakan salah satu kegiatan pemberdayaan masyarakat menggunakan konsep dan prinsip teknologi informasi guna membangun smart village secara benar, meningkatkan potensi pariwisata yaitu wisata baru, membuka peluang kerja dan tetap menjaga ekosistem. Bila tidak dijaga dan dikelola dengan baik dikhawatirkan suatu saat masyarakat Aikdewa akan terpengaruh oleh budaya luar yang kurang memiliki nilai ketimuran akibat tidak dipertahankannya nilai-nilai kearifan lokal bagi pelestarian ekosistem dan sumber daya alam. Masyarakat Aikdewa perlu memperoleh pengetahuan konsep-konsep dan teori yang bersifat teknologi informasi yang sesuai dan mendukung praktek-praktek pelestarian serta pengelolaan ekosistem dan kawasan wisata. Pengetahuan, tradisi dan nilai-nilai kearifan lokal dalam masyarakat Aikdewa yang berkaitan dengan praktek-praktek pelestarian ekosistem dan kawasan wisata perlu didukung oleh pengetahuan ilmiah yang relevan sehingga memperkuat nilai-nilai kearifan lokal.

Dengan pengetahuan teknologi informasi ini masyarakat Aikdewa diharapkan lebih memperkuat praktek dan pengetahuan lokalnya dalam mengelola ekosistem dan sumber daya alam, sehingga kawasan wisata dan ekosistem desa Aikdewa dapat dijadikan sebagai daerah resapan air. Jumlah mata air yang banyak harus tetap dilestarikan dan dapat dimanfaatkan secara berkelanjutan bagi kesejahteraan masyarakat terutama masyarakat Aikdewa guna mendukung pengembangan dan penerapan smart village

\section{UCAPAN TERIMAKASIH}

Untuk penyusunan artikel ini, pertama-tama ucapan syukur kepada Tuhan Yang Maha Esa Allah SWT atas nikmat hidup yang diberikan-Nya dan Nabi Muhammad SAW atas ajaran ilmu yang diturunkan kepada bumi dan seluruh isinya. Penulis juga mengucapkan terimakasih kepada Pimpinan Sekolah Tinggi atas dukungan dan motivasi sehingga artikel dapat terselesaikan dengan baik. Terimakasih pula kepada Tim Editor dan Reviewer Jurnal Teknimedia atas masukan dan diterimanya artikel ini untuk diterbitkan.

\section{DAFTAR PUSTAKA}

[1] Annisah, 2017, Usulan Perencanaan Smart City: Smart Governance Pemerintah Daerah Kabupaten Mukomuko, Jurnal Masyarakat Telematika dan Informasi Volume 8 No.1 (Januari-September 2017) Hal. 59-80 
[2] Asnamawati, L., Sara, D., dan Ellyunizar, 2017, Strategi Implementasi Smart City dalam Upaya Pemberdayaan Masyarakat Nelayan Kampung Sejahtera di Provinsi Bengkulu, Prosiding Seminar Nasional Tahunan Matematika, Sains dan Teknologi, 2017 Unviersitas Terbuka Conventional Center, 12 Oktober 2017

[3] Farania, A., Hardiana A., dan Putri R.A., 2017, Kesiapan Kota Surakarta dalam mewujudkan Pariwisata Cerdas (Smart Tourism) ditinjau dari Aspek Fasilitas dan Sistem Pelayanan, Region, Volume 12, No 1, Januari 2017: 36-50

[4] Herdiana, D., 2019, Pengembangan Konsep Smart Village bagi Desa-Desa di Indonesia, IPTEk-KOM, Vol. 21 No. 1, Juni 2019: 1-16 e-ISSN 2527-4902

[5] MZ, Siti Puspita Hida Sakti dan Marzuki, 2019, Smart City dalam Rencana Tata Bangunan dan Lingkungan (RTBL) Kawasan Kota Tua Ampenan, Book of Conference: Seminar Nasional Pengelolaan Sumber Daya Air dan Pengembangan Kawasan berbasis Ekowisata Menuju Bali Era baru (Ruang Sri Kesari Mandapa Warnadewa) Universitas Warmadewa Denpasar 13 Desember 2019

[6] MZ, Siti Puspita Hida Sakti dan Marzuki, 2019, Smart City pada Pengembangan Pariwisata Kawasan Kota Tua Ampenan berbasis Kearifan Lokal, JURTI Vol. 3 No.2 Desember 2019 ISSN: 2579-8790 Hal. 165171

[7] Rachamawati, R., 2018, Pengembangan Smart Village untuk Penguatan Smart City dan Smart Regency, Jurnal Sistem Cerdas 2018 Volume 01 No. 02 ISSN:2622-8254 Hal: 12-18, Asosiasi Prakarsa Indonesia Cerdas (APIC) -2018

[8] Redjeki, S., Faizal, E., Iskandar, E., Rosadi, D., dan Mustofa, K., 2018, Framework Pengembangan City Branding Kabupaten Bantul menggunakan Pendekatan Smart Tourism, Jurnal TAM (Technology Acceptance Model) Volume 9 No. 2 Desember 2018 Hal. 79-85 p-ISSN: 2339-1103 e-ISSN: 25794221

[9] Riyanti A., Mustofa, H., 2017, Implementasi Konsep Smart City dalam Aspek Lingkungan Studi Kasus: Kota Cimahi, Prosiding Seminar Nasional Tahunan Matematika, Sains dan Teknologi, 2017 Unviersitas Terbuka Conventional Center, 12 Oktober 2017

[10] Subekti, T., dan Damayanti, R., 2019, Penerapan Model Smart Village dalam Pengembangan Desa Wisata: Studi pada Desa Wisata Boon Pring Sanankerto Turen Kabupaten Malang, Jurnal of Public Admin- istration and Local Goverment (JPALG) Vol. 3 No. 12019 hal. 18-28 P-ISSN: 2614-4433 E-ISSN: 2614-4441, Program Administrasi Publik, Universitas Tidar

[11] Sugiyarto, Amaruli, R. J., 2018, Pengembangan Pariwisata berbasis Budaya dan Kearifan Lokal, Jurnal Administ rasi Bisnis, Volume 7 No. 1 Maret 2018 pp. 45-52 P-ISSN 2252-3294 E-ISSN 2548-4923

[12] Supriadi, A., Fadli H., M.N., dan Malik K., 2016, Membangun Sistem Smart Village untuk Menciptakan Ekonomi Masyarakat Desa Mandiri di Desa Alas Tengan Kecamatan Paiton Kabupaten Probolinggo berbasis Android, Prosiding SENTIA 2016 - Politeknik Negeri Malang Volume 8 ISSN: 2085-2347 